\title{
Determination of maximum working capacity of retrofittable cutters on the basis of physical- mechanical features of tool hard alloys
}

\author{
Evgeniy V. Artamonov ${ }^{1}$, Andrey M. Tveryakov ${ }^{1}$, Anton S. Shtin ${ }^{1, *}$ \\ ${ }^{1}$ Industrial University of Tyumen, Tyumen, Russian Federation
}

\begin{abstract}
This research is dedicated to the determination of maximum working capacity temperature of tool hard alloy cutters during a processing of parts by means of cutting made of hard-to-cut materials including assessment of possibility of using of tools made in Russian Federation without loss of the processing efficiency.
\end{abstract}

\section{Introduction}

Nowadays usually foreign metal-cutting tools of such manufacturers as: "Sandvik Coromant", "Mitsubishi", "Walter", "Iscar" is used for the processing of different materials. It is impossible to provide industrial activity of the country without usage of equipment and tools of home manufacture under current conditions of penalties and import substitution.

Today classified conditions for new hard-to-cut materials used in upcoming sec-tors of the industry of our country are chosen in correspondence with recommendations of manufacturing plants. These recommendations are quite general and do not provide maximum efficiency of mechanical processing of these materials.

Scientists Vereshchaka A.S.[1], Grigor'ev S.N.[2], Kushner V.S.[3], Loladze T.N.[4], Makarov A.D.[5], Poletika M.F.[6], Silin S.S.[7], Uteshev M.H.[8], SHalamov V.G.[9], Neugebauer, R. [10], Zhang, H.[11] and others dedicated their papers to this problem.

The research objective is to determine maximum working capacity of the cutting elements made of tool hard alloys.

It is necessary to solve the following tasks in the furtherance of this goal:

1. Conduction of literary analysis.

2.Study known methods of the determination of maximum working capacity of the cutting elements made of tool hard alloys according to the physical-mechanical characteristics.

3. Research of possibility of determination of maximum working capacity temperature of retrofittable hard alloy cutting elements on the basis of change of electromagnetic features of the tool hard alloys because of the temperature.

The topic of this research is a cutting blade made of the tool hard alloy.

\footnotetext{
* Corresponding author: shtin as@mail.ru
} 


\section{A description of the researches}

The literature analysis showed that the determinative factor in all interrelation of events during cutting of materials is a temperature-power factor in mix with physical-mechanical characteristics of a tool and processable materials [12], [13].

The ability of hard alloys to save high enough hardness and resist to distorting under high temperature in mix with satisfying endurance is an important advantage over other tool materials.

Working capacity of the cutting tool is a condition at which the tool is able to conduct prescribed functions having wear and tear of working surfaces less than criterial [1].

Nowadays there is variety of methods of determination of maximum working ca-pacity temperature of hard alloys according to physical-mechanical characteristics in a lab environment [12].

Part of research dedicated to determination maximum working capacity tempera-ture is based on mechanical characteristics of tool hard alloys such as dependence of tensions intensity $\mathrm{K} 1 \mathrm{C}$ and dependence of impact force $\mathrm{KCV}$ on a temperature [13].

Mechanical characteristics react very good on structural changes caused by the temperature. That is a doubtless advantage of these methods.

The main insufficiencies are (as earlier) a necessity of production of special sam-ples for tests, complexity of calculations. All these factors increase probability of errors in the determination of maximum working capacity temperature of the retrofittable car-bide blades.

Another part of research is based on physical characteristics of the tool hard alloys that react also good on structural changes caused by the temperature.

There is a method based on dependence of lgHV from the temperature. The insufficiency of this method is complexity of determination of $\operatorname{lgHV}$ and amount of error of the results.

Electrical conductivity of hard alloys is also used to determine maximum working capacity temperature.

The method of the determination of maximum working capacity temperature ac-cording to electrical conductivity features of the tool hard alloys is based on dependence of electrical conductivity of these tools from the temperature, see pic. 1



Fig. 1. Dependence diagrams of electrical conductivity on the temperature of tool hard alloy WC- 8 Co

During the analysis of the diagram we receive a temperature band for alloy WC- 8 Co $630^{\circ}-750^{\circ} \mathrm{C}$, which corresponds to the lowest value of electrical conductivity and maximum working capacity of this hard alloy [14], [15], [16]. 
The insufficiency of this method is a necessity to conduct mathematical calculations according to the results of the experiments and also impossibility to conduct tests on samples with a cover. Therefore we continued search of a temperature change sensitive characteristic of the hard alloy which also should be able to reflect condition of the alloy.

\section{Results and their discussion}

The hard alloy has features of electrical conductivity and electro-magnetic features at the expense of its chemical formula [14]. There-fore the following task of the research is to study a possibility of the determination of maximum working capacity temperature of retrofittable cutting elements on the basis of the dependence of the electro-magnetic features of tool hard alloys on the temperature.

There was made a decision to create a new method based on a change of the electromagnetic features of the tool hard alloys and allows to conduct measurements of change of values of the characteristics by means of a noncontact method. This decision was made in order to clear insufficiencies found during the research of the known methods of the determination of maximum working capacity temperature. In the furtherance of this goal a special mounting was developed (pic. 2). This mounting consists of: a self-excited oscillator 1 , a voltage meter, a spool 3, a retrofittable carbide blade 4 . This mounting generates a magnetic field that stimulates eddy-currents on the surface of the retrofittable carbide blade.



Fig. 2. A pattern of the new mounting for determination of maximum working capacity temperature according to the change of electro-magnetic features.

Maximum working capacity temperature is determined by the change of values of the electro-magnetic field eddy-currents targetable in the retrofittable carbide blade made of the hard alloy tool in the temperature range specific to processing of metals by cutting. The fixation is conducted by an indirect method according to the changes of EMF (electromotive force) of a spool of a self-maintained contour with the cutting carbide blade made of the tool hard alloy and placed inside of the spool, shown on pic. 3 . 




Fig. 3. Dependence of the spool EMF of the self-maintained contour on the tem-perature of tool hard alloy WC- 8 Co

The received temperature range for single carbide hard alloy WC- 8 Co $530^{\circ}-750^{\circ} \mathrm{C}$, corresponds to the maximum values of the spool EMF of the self-maintained contour and it is a temperature range of the conditions of this tool alloy maximum working capacity, that correlates authentically with the above-mentioned method [5], [15]. Not only the received data matches completely with results of research of famous scientists but also allows authentically determine conditions of maximum working capacity of the carbide blades made of tool hard alloys without expensive wear tests. It fits to alloy of any manufacturers, both foreign such as: "Sandvik Coromant", "Mitsubishi", "Walter", "Iscar" or native, such as "K3TC", (Kirovograd plant of hard alloys).

\section{Conclusions}

Therefore, literature analysis and study of all known methods of determination of maximum working capacity temperature showed that all the above-mentioned method fit well to the determination of conditions of maximum working ca-pacity of the tool hard alloys, but each of them has its own advantages and insufficiencies. The research of possibility of determination of maximum working capacity temperature of the retrofittable cutting hard alloy elements on the basis of change of electro-magnetic features of tool hard alloys in dependence on temperature showed that electro-magnetic fields of the tool hard alloys react well on temperature changes and the received temperature intervals correlate well with the results of the known methods. This research showed that the method of determination of maximum working capacity temperature according to the change of the electro-magnetic features allows to determine maximum working capacity temperature with no need for production of special samples and without additional mathematical calculations. Under current conditions of import substitution when a foreign tool is used for a processing of vital parts made of difficult to machine materials it is necessary to replace it with the home one. They are almost identical according to the chemical formula. The difference is only in that foreign manufacturers hold in confidence secrets of the chemical formula. During the determination of the conditions of maximum working capacity of tool hard alloys, with the help of the scientifically grounded method based on the change of the values of the electromagnetic field eddy-currents targetable in the retrofittable carbide blade, hard alloys of home manufacture will be able not only to compete with foreign manufacturers of tools but also to replace them at the critical sectors of the industry, where safety of citizens of our country can depend on the quality of the processed surface. 


\section{References}

1. Vereshchaka A.S. Rabotosposobnost' rezhushchego instrumenta s iznosostojkimi pokrytiyami. / Vereshchaka A.S. - M.: Mashi-nostroenie, 1993. - 336 s.: il. — (B-ka instrumental'shchika). — ISBN 5-217-01482-2.

2. Grigor'ev, S.N. Metody povysheniya stojkosti rezhushchego instrumenta: uchebnik dlya studentov vtuzov [EHlektronnyj resurs] : ucheb. - EHlektron. dan. — Moskva : Mashinostroenie, 2009. - $368 \mathrm{~s}$.

3. Vasin S.A. Rezanie materialov: Termo-mekhanicheskij podhod $\mathrm{k}$ sisteme vzaimosvyazej pri rezanii: uchebnik dlya tekhnicheskih vyzov. / S.A. Vasin, A.S. Vereshchaka, V.S. Kushner - M.: Izd-vo MGTU im. N.EH. Baumana, 2001.-448 s.

4. Loladze T.N. Prochnost' i iznosostoj-kost' rezhushchego instrumenta. / T.N. Loladze M.: Mashinostroenie, 1982. - $320 \mathrm{~s}$.

5. Makarov, A.D. Optimizaciya processov rezaniya. / A.D. Makarov, 2-e izd. - M.: Mashi-nostroenie, 1976. - 278.

6. Poletika, M.F. Kontaktnye nagruzki i tem-peratury na iznoshennom instrumente. / M.F. Poletika, V.N. Kozlov // Progressivnye tekhnologicheskie processy v mashinostroenii: Sbornik nauchnyh trudov. - Tomsk: TPU, 1997. - s.18-21.

7. Silin S.S. Metod podobiya pri rezani metallov / S.S. Silin - M.: Mashinostroenie, 1979.- $152 \mathrm{~s}$.

8. Zorev N.N. Untersuchung der Kintakt-spannunger auf den Arbeits-flachen des Werkzeugs miteiner Schneidenabrundung / Zorev N.N., Uteshev M.H. - Berichte der Internationalen Forschungesgemein-schaft fur mechanische produktionstechniktionstechnik Vol. 20-1 Schweiz, 1971.

9. Shalamov V.G. Savel'ev D.A., Smetanin S.D. Producing powder by rotary grinding. Aller-ton Press, Inc. (New York) Volume 33, Issue 3, 2013, Pages 133-135 DOI: 10.3103/S1068798X13030167

10. Neugebauer, R., Hochmuth, C. Schmidt, G., Dix, M. Energy efficient process planning based on numerical simulations. Advanced Materials Research 2011, Volume 223, Pages 212-221, 17th CIRP Conference on Modelling of Machining Operations; Sintra; Portugal; 12 May 2011 до 13 May 2011. DOI: 10.4028/www.scientific.net/AMR.223.212.

11. Zhang, H., Fang, Z.Z., Lu, Q. Characterization of a bilayer WC-Co hardmetal using Hertzian indentation technique. International Journal of Refractory Metals and Hard MaterialsVolume 27, Issue 2, March 2009, Pages 317-322. DOI: 10.1016/j.ijrmhm.2008.07.014.

12. Artamonov E.V., Prochnost' i raboto-sposobnost' smennyh tverdosplavnyh plastin sbornyh rezhushchih instrumentov, Tyumen', Vektor Buk, 2003, 190. ISBN: 5-88465416-2.

13. Vasilega, D.S., Shtin, A.S., Method for the determination of hard alloys' maximum performance temperature in the context of the metal-cutting tools' usage quality estimation technique.// Key Engineering Materials 737 M, c. 59-63, 2017.

14. Artamonov E.V., Vasilega D.S., Tverya-kov A.M., Opredelenie temperatury maksimal'noj rabotosposobnosti tverdosplavnyh rezhushchih plastin na osnove ehlektricheskoj provodimosti. // Zavodskaya laboratoriya. Diagnostika materialov. T. 80. № 9, 36-39. 
15. Tveryakov, A.M., Shtin, A.S., Setup for determining the maximum temperature for increased performance longevity of replaceable cutting discs.// AIP Conference Proceedings, 1785,040088, 2016. DOI: 10.1063/1.4967145.

16. Patent RF №172959 MPK B23B1/00. Ustanovka dlya opredeleniya temperatury maksimal'noj rabotosposobnosti tverdosplavnyh rezhushchih plastin / E.V. Artamonov, A.M. Tveryakov, A.S. SHtin - Zayavka №2016130884 ot 26.07.2016. Opubl. 02.08.2017 Byul.№22. 